\title{
Peran Interleukin-6 dalam Menilai Respon Pengobatan pada Sepsis Neonatorum Awitan Dini
}

\author{
Rudy Ciulianto, Max F. J. Mantik, Rocky Wilar, Suryadi N.N. Tatura \\ Bagian Ilmu Kesehatan Anak Fakultas Kedokteran Universitas Sam Ratulangi, Manado
}

Latar belakang. Interleukin-6 memiliki potensi untuk menilai respon pengobatan selain sebagai biomarker sepsis.

Tujuan. Menentukan peran IL-6 dalam mengevaluasi respon pengobatan pada sepsis neonatorum awitan dini (SNAD).

Metode. Kami melakukan penelitian potong lintang dengan sampel SNAD yang memenuhi kriteria penelitian dengan jumlah sampel sebanyak 40 bayi dan mendapatkan informed consent dari orang tua serta persetujuan komite etik RSUP Kandou. Analisis data menggunakan uji Wilcoxon dan uji t berpasangan.

Hasil. Dari 40 sampel, terdapat 12 bayi laki-laki dan 3 bayi perempuan mengalami respon buruk. IL-6 sebelum dan sesudah terapi antibiotik pada kelompok respon baik memiliki nilai median 16,32 (Qd 5,23) dan 0,56 (Qd 0,46). Kelompok respon buruk memiliki nilai rerata IL-6 120,89 (SB 87,35) dan 503,71 (SB 479,97). Hasil uji Wilcoxon menyatakan penurunan IL-6 yang sangat bermakna terhadap kelompok respon baik $(\mathrm{p}<0,0001)$, begitu juga pada kelompok respon buruk terjadi peningkatan yang sangat bermakna dengan hasil uji t berpasangan ( $\mathrm{p}=0,004)$.

Kesimpulan. IL-6 merupakan biomarker yang dapat dipertimbangkan untuk menilai respon pengobatan pada SNAD, IL-6 akan menurun jika diberikan antibiotik yang tepat. Sari Pediatri 2017;19(1):32-5

Kata kunci: IL-6, SNAD, respon pengobatan

\section{The Role of Interleukin-6 as A Treatment Response Evaluation in Early Onset Neonatal Sepsis}

\author{
Rudy Ciulianto, Max F. J. Mantik, Rocky Wilar, Suryadi N.N. Tatura
}

Background. Interleukin- 6 has the potential to assess treatment response aside from sepsis biomarker.

Objectives. To determine the role of IL-6 in evaluating treatment response in early onset neonatal sepsis (EONS).

Methods. We conducted cross sectional study with the sample of EONS that met the study criteria with 40 samples, getting informed consent from the parents and approval of a research ethics committee of Kandou hospital. Data analysis using Wilcoxon test and paired t-test.

Results. Of the 40 samples, there were 12 baby boys and 3 baby girls experiencing poor response treatment. IL- 6 before and after antibiotic therapy in good response group had a median of $16.32(\mathrm{Qd} 5.23)$ and $0.56(\mathrm{Qd} 0.46)$. In poor response group had a mean of IL-6 120.89 (SD of 87.35) and 503.71 (SD 479.97). Wilcoxon test results showed a very significant declined in the IL-6 levels to good response group $(\mathrm{p}<0.0001)$, so are with the paired t-test results in the group of poor response, showed a very significant increased $(\mathrm{p}=0.004)$.

Conclusions. Interleukin-6 is a biomarker that could be considered to assess treatment response in EONS. Sari Pediatri 2017;19(1):32-5

Keywords: IL-6, EONS, treatment response

Alamat korespondensi: Dr. Rudy Ciulianto. Bagian Ilmu Kesehatan Anak, RSUP Prof Dr. RD Kandou. Jln Raya Tanawangko No.56, Manado. E-mail :chow_dr5@yahoo.com 
S epsis neonatorum merupakan masalah global dan masih memberikan kontribusi yang signifikan terhadap kecacatan dan kematian. Dalam satu tahun, setidaknya terjadi satu juta kematian pada periode bayi baru lahir (0-28 hari) yang disebabkan oleh infeksi. Hampir 25\% infeksi merupakan penyebab kematian bayi baru lahir (BBL) di seluruh dunia dan $10 \%$ dari semua bayi yang meninggal. ${ }^{1}$

Angka kematian bayi baru lahir merupakan indikator kemajuan kesehatan suatu negara. ${ }^{2}$ Menurut data Survei Demografi Kesehatan Indonesia tahun $2012,{ }^{3}$ tercatat 32 kematian per 1.000 kelahiran hidup. Di Sulawesi Utara, data yang diperoleh dari Dinas Kesehatan tahun 2013 terdapat 331 kasus kematian bayi baru lahir atau 2,2 kematian per 1.000 kelahiran hidup, di kota Manado sendiri dilaporkan 46 kematian selama periode tahun $2013 .{ }^{4}$

Prognosis dan luaran sepsis neonatorum bergantung pada diagnosis yang cepat dan terapi antibiotik yang efisien. ${ }^{5}$ Diagnosis sepsis neonatorum yang akurat dan tepat waktu masih menjadi tantangan dan bermasalah dikarenakan presentasi klinis yang tidak spesifik, hasil diagnostik hanya mencapai sensitivitas $50 \%$ atau kurang dan hasil kultur darah yang lama. Oleh karena itu, sampai saat ini banyak penelitian dilakukan untuk mengembangkan tes diagnostik cepat dan sensitif untuk diagnosis BBL yang terinfeksi. ${ }^{6}$

Pemberian antimikroba awal yang tepat diperlukan untuk memperbaiki luaran pasien sepsis. Selain digunakan sebagai parameter baru dalam menegakkan diagnosis sepsis pada bayi baru lahir, interleukin-6 juga dapat digunakan untuk menilai sebuah respon pengobatan. Hanya beberapa penelitian yang telah menguji kinetik daripada IL-6 untuk memonitor pengobatan pada kelompok sepsis bakterial berat maupun syok septik, terutama pada pasien anak dan dewasa. Namun, masih sedikit yang terfokus pada penderita SNAD yang dirawat di NICU. Oleh karena itu, kami melakukan penelitian mengenai peran IL-6 dalam menilai respon pengobatan pada SNAD.

\section{Metode}

Penelitian analitik observasional dengan pendekatan potong lintang dilakukan di Neonatal Intensive Care Unit (NICU) RSUP Prof. dr. R.D. Kandou Manado mulai bulan Juni 2016 - September 2016. Sampel penelitian adalah bayi SNAD yang dikumpulkan dengan cara consecutive sampling dengan jumlah sampel 40 bayi. Kriteria inklusi adalah semua bayi baru lahir cukup bulan dengan SNAD, lahir secara pervaginam atau sectio caesaria, mendapat persetujuan dari orang tua untuk mengikuti penelitian dengan menandatangani formulir persetujuan (informed consent). Penelitian ini dilaksanakan di bawah persetujuan komite etik RSUP Prof R.D. Kandou Manado. Bayi dengan kelainan bawaan, asfiksia neonatorum, infeksi hati, prematuritas/bayi berat lahir rendah, bayi yang meninggal sebelum pengambilan sampel IL-6 yang kedua, tidak terbukti sepsis atau syok septik tidak diikutsertakan dalam penelitian.

Selama penelitian berlangsung, bayi dibagi menjadi 2 kelompok berdasarkan respon pengobatan, yakni baik dan buruk. Definisi respon baik adalah bayi dengan perbaikan klinis setelah pemberian antibiotik berupa $2 \times 24$ jam bebas gejala klinis sepsis, seperti normotermia (suhu aksilar $36,5^{\circ} \mathrm{C}-37,5^{\circ} \mathrm{C}$ ), denyut jantung $100-160 \mathrm{x} / \mathrm{menit}$, frekuensi napas 30-60 x/ menit, aktif, menangis kuat, asupan baik, dan tanpa ada gangguan hematologis. Sementara respon buruk adalah bayi dengan perburukan klinis lebih dari 12 jam setelah pemberian antibiotik dengan minimal 4 gejala dari 6 gejala klinis sepsis neonatorum, seperti instabilitas suhu (hipotermi dengan suhu aksilar $<36,5^{\circ} \mathrm{C}$, demam dengan suhu aksilar $>37,5^{\circ} \mathrm{C}$ ), bradikardi $(<100 \mathrm{x} /$ menit $)$ atau takikardia $(>160 \mathrm{x} /$ menit), takipnea (frekuensi napas $>60 \mathrm{x} /$ menit) atau bradipnea (frekuensi napas $<30 \mathrm{x} /$ menit), penurunan aktivitas, menangis lemah, asupan kurang, dan disertai adanya gangguan hematologis. Analisis statistik menggunakan program SPSS versi 22. Analisis deskriptif untuk menganalisis data karakteristik, uji Wilcoxon dan t berpasangan untuk mengevaluasi kadar IL-6 dalam menilai respon pengobatan. Kemaknaan hasil uji ditentukan berdasarkan nilai $\mathrm{p}<0,05$.

\section{Hasil}

Didapatkan 40 bayi yang memenuhi kriteria inklusi, terdiri atas 22 laki-laki dan 18 perempuan, 12 bayi laki-laki dan 3 bayi perempuan mengalami respon pengobatan buruk. Kultur darah dilakukan pada 40 bayi dengan hasil 5 pertumbuhan positif, yaitu Klebsiella pneumoniae (2), Enterobacter aerogenes (2) dan Staphylococcus aureus (1). 
Tabel 1. Hasil pengujian perbandingan kadar IL-6 serum pada SNAD

\begin{tabular}{|c|c|c|c|}
\hline \multirow{2}{*}{ Variabel } & \multicolumn{2}{|c|}{ Kadar IL-6 (pg/ml) } & \multirow{2}{*}{$\mathrm{p}$} \\
\hline & Awal & Akhir & \\
\hline Respon baik $(n=25)$ & & & $<0,0001^{*}$ \\
\hline Median & 16,32 & 0,56 & \\
\hline $\mathrm{Qd}$ & 5,23 & 0,46 & \\
\hline Respon buruk ( $\mathrm{n}=15)$ & & & $0,004^{* *}$ \\
\hline Rerata & 120,89 & 503,71 & \\
\hline SB & 87,35 & 479,97 & \\
\hline
\end{tabular}

Pada Tabel 1 memperlihatkan perbedaan yang sangat bermakna kadar IL-6 serum awal dan akhir pada kelompok SNAD dengan respon pengobatan baik $(\mathrm{p}<0,0001)$, kadar IL-6 akan menurun setelah diberikan terapi antibiotik. Pada kelompok SNAD yang mengalami respon pengobatan buruk juga menunjukkan adanya perbedaan kadar IL-6 serum awal dan akhir yang sangat bermakna $(\mathrm{p}=0,004)$, kadar IL-6 akan meningkat walaupun telah diberikan terapi antibiotik.

\section{Pembahasan}

Kadar IL-6 serum awal dan akhir pada kelompok respon pengobatan baik akan menurun setelah diberikan antibiotik, sedangkan pada kelompok respon pengobatan buruk akan meningkat. Hasil tersebut memperlihatkan bahwa terapi antibiotik memengaruhi kadar IL-6 serum. Pemberian antibiotik yang tepat akan menurunkan kadar IL-6 serum pada kelompok bayi dengan respon baik. Namun, hal sebaliknya terjadi pada kelompok bayi dengan respon buruk, kadar IL-6 serum akan meningkat yang menggambarkan bahwa adanya kemungkinan pemberian antibiotik yang kurang tepat sehingga kuman patogen tidak berhasil dimatikan yang akan tetap memproduksi IL-6 menjadi lebih banyak.

Hasil penelitian kami ini didukung oleh hasil penelitian sebelumnya, seperti sebuah studi kasus kontrol prospektif terhadap bayi sepsis menyimpulkan bahwa kadar IL-6 serum akan menurun pada kelompok SNAD yang mengalami respon pengobatan baik apabila diberikan terapi antibiotik yang tepat. Sebaliknya, kadar IL-6 serum akan meningkat apabila terapi antibiotik yang diberikan kurang tepat. ${ }^{9}$

Hasil studi lain yang dilakukan oleh Jekarl dkk ${ }^{10}$ secara kohort memperlihatkan bahwa pada pengukuran serial pada pasien sepsis, terutama pada 96 jam pertama saat dirawat, $86 \%$ kelompok yang bertahan hidup menunjukkan penurunan kadar IL-6 setelah 48 jam. Sebaliknya, pada kelompok yang tidak bertahan hidup terjadi peningkatan kadar IL-6 serum.

King dkk ${ }^{11}$ melaporkan bahwa kadar IL-6 menurun cepat pada kelompok yang sembuh, sedangkan kelompok yang memburuk bahkan meninggal menunjukkan peningkatan pada 24-48 jam pertama. Oleh karena itu, konsentrasi IL-6 dapat menjadi prediktor terhadap terapi antibiotik yang tepat pada 24-48 jam pertama pada sepsis bakterial berat maupun syok septik. Selain itu, Kocabas dkk ${ }^{12}$ melaporkan bahwa kadar IL-6 serum menurun secara drastis pada kelompok bayi sepsis yang mengalami perbaikan pada hari ketiga dan ketujuh setelah diterapi dengan antimikroba. Sedangkan, pada kelompok bayi sepsis yang meninggal selama pengobatan, kadar IL-6 serum meningkat drastis.

Beberapa penelitian yang dilakukan di Jepang menunjukkan adanya hubungan IL-6 terhadap pasien sepsis maupun SIRS. Penelitian yang dilakukan pada kelompok dewasa usia 19-80 tahun dengan sepsis berat maupun SIRS memperlihatkan bahwa kadar IL-6 serum pada hari pertama, 6 kali lebih tinggi pada kelompok yang tidak bertahan hidup bila dibandingkan dengan kelompok yang bertahan hidup. ${ }^{13}$ Penelitian yang lain juga melaporkan hasil yang sama, pada kelompok dewasa dengan SIRS, sepsis, sepsis berat maupun syok septik diperoleh setelah pengukuran kadar IL-6 secara berturut-turut pada pasien dengan sepsis/SIRS menunjukkan bahwa kadar IL-6 lebih tinggi pada kelompok yang tidak bertahan hidup. Sementara kadar tersebut akan menurun cepat setelah pengobatan pada kelompok yang bertahan hidup. ${ }^{14}$

Bakteri akan memicu kaskade sepsis yang dimulai dengan aktivasi sistem koagulasi dan komplemen, pelepasan tissue factor (TF), aktivitas fibrinolisis dan aktivasi makrofag. Aktivasi makrofag menyebabkan dilepaskannya sejumlah mediator inflamasi primer, salah satunya adalah IL-6. Sitokin ini berfungsi sebagai regulator reaksi tubuh terhadap infeksi, inflamasi, atau trauma. ${ }^{15}$ Pemberian antibiotik untuk penderita sepsis bakterial merupakan salah satu tantangan terapeutik yang paling penting, karena mortalitas jelas bergantung pada pengobatan yang tepat dan cepat.16 Oleh karena itu, kebanyakan strategi terapeutik bergantung pada pemberian antibiotik pertama kali yang tepat dan 
bersifat spektrum luas sehingga diharapkan antibiotik dapat memutuskan kaskade sitokin yang terjadi pada sepsis dan menurunkan produksi sitokin, terutama sitokin proinflamasi. Di samping itu, para klinisi sering dibingungkan untuk membuat keputusan apakah harus mengganti suatu antibiotik yang sudah diberikan sejak awal. ${ }^{17}$

Pada penelitian ini ditunjukkan bahwa IL-6 dapat dipertimbangkan sebagai parameter untuk mengevaluasi respon pengobatan pada bayi SNAD dan membantu para klinisi untuk memutuskan apakah pemberian antibiotik perlu dilanjutkan atau diganti dengan antibiotik yang lebih poten. Studi ini juga memiliki keterbatasan, hasil penelitian tidak menentukan cut off point kadar IL-6 serum sebagai kemungkinan faktor prediktor mortalitas dikarenakan penelitian ini merupakan penelitian awal. Untuk penelitian selanjutnya, perlu dilakukan sebuah studi analisis prospektif IL-6 terhadap luaran sepsis neonatorum dengan menggunakan panduan tata laksana antimikroba ataupun IL-6 sebagai faktor prediktor terhadap kejadian mortalitas pada SNAD maupun SNAL dan mungkin dapat dibandingkan dengan biomarker lainnya yang sudah ada sebelumnya seperti CRP dan prokalsitonin.

\section{Kesimpulan}

Interleukin-6 merupakan biomarker yang dapat dipertimbangkan untuk menilai respon pengobatan pada sepsis neonatorum awitan dini.

\section{Daftar pustaka}

1. Black RE, CousensS, Johnson HL. Global, regional, and national causes of child mortality in 2008: a systematic analysis. Lancet 2010;375:1969-87.

2. Aminullah A. Sepsis pada bayi baru lahir. Dalam: Kosim MS, Yunanto A, Dewi R, Sarosa GI, Usman A, penyunting. Buku ajar neonatologi. Edisi 1. Jakarta: Badan Penerbit IDAI 2012.h.170-87.

3. Departemen Kesehatan Republik Indonesia 2012. Survei demografi dan kesehatan Indonesia. Diakses 14 Maret 2016. Didapat dari: URL:http://depkes.co.id/1456-depkes-target- mdgs-bidang-kesehatan.html.

4. Dinas Kesehatan Provinsi Sulawesi Selatan 2012. Profil kesehatan Provinsi Sulawesi Utara Tahun 2012. Diakses 14 Maret 2016. Didapat dari: URL:http://www.depkes.go.id/resources/ download/profil/PROFIL_KES_PROVINSI_2012/24_Profil_ Kes.Prov.SulawesiUtara_2012.pdf

5. Kliegman, Stanton, St. Geme and Schor. Infections in neonates: etiology of fetal \& neonatal infection. Dalam: Kliegman RM, Behrman RE, Jenson HB, Stanton BF, penyunting. Nelson text book of pediatrics. Edisi ke-20. Philadelphia: Elsevier 2015.h.794-811.

6. Mishra UK, Jacobs SE, Doyle LW. Newer approaches to the diagnosis of early onset neonatal sepsis. Arch Dis Child Fetal Neonatal Ed 2006; 91:F208-12.

7. Kingsmore SF, Kennedy N, Halliday HL, dkk. Identification of diagnostic biomarkers for infection in premature neonates. Mol Cell Proteomics 2008;7:1863-75.

8. Lam HS, Ng PC. Biochemical markers of neonatal sepsis. Pathology 2008;40:141-8.

9. Boskabadi H, Maamouri G, Afshari J. Evaluation of serum interleukins-6, 8 and 10 levels as diagnostic markers of neonatal infection and possibility of mortality. Iran J Basic Med Sci 2013;16:1232-7.

10. Jekarl DW, Lee SJ, Lee J. Procalcitonin as a diagnostic marker and IL-6 as a prognostic marker for sepsis. Diagn Microbiol Infect Dis 2013;75:342-7.

11. King T, Cantara G, Sechtem U. Interleukin-6 kinetics can be useful for early treatment monitoring of severe bacterial sepsis and septic shock. Infect Dis Rep 2016;8:6213.

12. Kocabaş E, Sarıkçıŏlu A, Aksaray N. Role of procalcitonin, C-reactive protein, interleukin-6, interleukin-8 and tumor necrosis factor- $\alpha$ in the diagnosis of neonatal sepsis. Turk J Pediatr 2007;49:7-20.

13. 13. Miki T, Iba T. Kinetics of circulating damage-associated molecular patterns in sepsis. J Immunol Res 2015;15:1-8.

14. Oda S, Hirasawa H, Shiga H. Sequential measurement of IL-6 blood levels in patients with systemic inflammatory response syndrome (SIRS)/sepsis. J Cytokine 2005;29:169-75.

15. Wynn JL, Wong HR. Pathophysiology and treatment of septic shock in neonates. Clin Perinato 2010;37:439-79.

16. Angus DC, van der Poll T. Severe sepsis and septic shock. N Engl J Med 2013;369:840-51.

17. Davies SW, Efird JT, Guidry CA. Characteristics of surgical patients receiving inappropriate empiric antimicrobial therapy. J Trauma Acute Care Surg 2014;77:546-554. 